\title{
Economic Evaluation of Asella Model-III Multi-crop Thresher
}

\section{Tamrat Gebiso Challa}

Socioeconomics Research Team, Asella Agricultural Engineering Research Center, Oromia Agricultural Research Institute, Asella, Ethiopia

\section{Email address:}

tameulove@yahoo.com,gebisochalla@gmail.com

\section{To cite this article:}

Tamrat Gebiso Challa. Economic Evaluation of Asella Model-III Multi-Crop Thresher.International Journal of Agricultural Economics. Vol. 3, No. 3, 2018, pp. 45-52. doi: 10.11648/j.ijae.20180303.12

Received: April 5, 2018; Accepted: April 18, 2018; Published: May 22, 2018

\begin{abstract}
Wheat is one of the most popular crops in Arsi zone produced covering major farmlands specially on midhighlands and parts of highland areas. Its production system is more advanced and supported by both biological and mechanical technologies relative to other crops in this area. But the mechanization of wheat is threatened by topographical inaccessibility in most highland areas of the zone. To solve this problem Asella Agricultural Engineering research center developed and tested its third version multi-crop thresher. Before the wider multiplication and dissemination of the technology, technical, economical and social acceptance and feasibility of the machine has to be studied. Therefore, this research activity was initiatedwith the objectives of evaluating financial, economicaland social feasibility of the machine vis-à-vis traditional and combines harvesting methods in Arsi zone under farmers' conditions. Accordingly, the newly developed Asella model-III thresher was found to be economical compared to traditional animal trampling method.
\end{abstract}

Keywords: Economic Evaluation, Multi-crop Thresher, Combine Harvesting, Partial Budgeting, Pay-Back Period, Internal Rate of Return, Sensitivity Analysis

\section{Background and Justification}

The history of agricultural mechanization in Arsi goes back to $1960^{\text {th }}$ when Chilalo Agricultural Development Unit (CADU)'s farm implement promotion and improvement section started the evaluation and comparison of especially, local (conventional) harvesting and threshing farm implements against improved machineries and found substantial output loss in case of conventional harvesting and threshing techniques [1], [2], and [3]. After that evaluation, CADU continued the promotion of pre harvest, harvest and post harvest farm machineries until the program was forced to discontinue by policy makers in 1972, even though the economic feasibility and technical viability of the new methods were confirmed [4].The main consequences of promoting the new methods during 1972 were reported to be the eviction of tenants, increased unemployment and soil erosion [5], [6] and [7].

Since 1974, the use of Agricultural mechanization machineries by individual small scale farmers was totally forbidden and only producer cooperatives were allowed to use those machineries until the producer cooperatives were dismantled by 1991 [8]. After the political and economic structural reform of 1991, small scale farmers started benefiting from the use of farm machineries by hiring from private investors and some multipurpose cooperatives.

Wheat is one of the most popular crops in Arsi zone produced covering major farmlands specially on midhighlands and parts of highland areas. Its production system is more advanced and supported by both biological and mechanical technologies relative to other crops in this area. Unless the farmer is resource poor to use, tractor, tractor mounted planters and combine harvester are all available through renting from cooperatives and private machinery holders. But this mechanical technology intervention is constrained by inaccessibility due to topography of most parts of the zone.

Most farmers having good topography of farm lands are hiring combine harvesters while some of the others are buying and/or hiring the stationary motorized (engine driven) threshers. Different organizations including Asella Agricultural engineering research center, are manufacturing different models of this stationary engine driven threshers type and farmers are using these technologies. However, the 
economic feasibility and social viability of those alternative methods of threshing and harvesting must be assessed and compared with conventional methods before embarking on mass production and recommendation of the techniques.

\section{Objectives of the Study}

There have been different arguments between mechanization favoring and disfavoring groups in Ethiopian and all over the world's agriculture regarding the impact of agricultural mechanization on production and productivity. The mechanization favoring groups argue that net productivity gained due to farm mechanization while the agricultural mechanization disfavoring group who considered agricultural mechanization as the substitute for animal and human labourdisplacing technology, argue that there is no significant net efficiency gains in terms of higher output and no reduction in production cost. Even if there higher production output, it will be offset by higher production cost specially when resources are valued in terms of social efficiency price rather than private efficiency prices[7] and [9].

Therefore, this study is initiated to assess the economical and social feasibility of stationary engine driven threshing method vis-à-vis the combine harvesting and conventional methods/a comparative assessment of a manual sickling and motorized stationary machine threshing Vis-à-vis a combine harvesting and traditional threshing in Arsi and West Arsi with the following specific objectives.

1. To describe the current threshing technologies in Arsi and West Arsi zones

2. Assess and compare the socioeconomic profitability ofalternative harvesting and threshing technologies

\section{Research Methodology}

\subsection{The Study Area}

This research was conducted in Arsi zone two districtsnamelyLemu-bilbilo and Hetosaselected based on preliminary information for the exposure/experience to stationary engine driven threshing machine and combine harvester for hiring in the area. Wheat is the main crop in terms of land allocation and production in both districts. There are also efforts which have been done to mechanize wheat farms in these areas and the effort of Asella agricultural engineering research center can be mentioned as one which develop, modify and adapt different pre-harvest and harvest technologies. Recently, tractor and combine harvesting are expanding in most parts of highland areas. There are some threshing technologies being transferred to farmers in this area while their comparative advantages over combine harvesting and traditional harvesting were not studied.

\subsection{Data Type and Methods of Data Collection}

Both primary and secondary data types were used in this research. Primary data were collected from farmers both on farm basis by checklists and using structured questionnaires. To compute the comparative economics of the three threshing mechanisms, OARI-Asela model-3 multi crop thresher was used and primary data was collected on field. The data collected include demographic and socioeconomic characteristics of the respondents, information on wheat production and threshing (wheat farming characterization). Additionally, FGD was undertaken with key informants like model farmers, DAs, investors of agricultural machineries rent service providers, and different stakeholders at different levels. To collect harvesting and threshing cost of each mechanism (i.e. to make comparison among different threshing mechanism), actual and estimation by respondents at each PA was collected during the season using Asela model-3 multi crop thresher, combine harvester and localor/traditional animal trampling mechanism on plate of field called hogdi/awudima.

\subsection{Data Analysis Methods}

Data analysis method is determined by objective of the research, and type of data collected. In this research activity, there are qualitative data which are views and comments from different experts, farmers and development agents and these data were analyzed qualitatively. To conduct the comparative analysis of wheat threshing techniques, partial budgeting was employed. To summarize the demographic and socioeconomic characteristics of the respondents, descriptive and inferential statistics were employed. To estimate the economic feasibility of threshing techniques, internal rate of return and machine pay-back period of engine driven threshing method were calculatedfollowing [10].

\section{Result and Discussion}

\subsection{Socioeconomic Characteristics and Resource Ownership of the Respondents}

The result in Table 1 shows that the mean age of respondents was about 45 years while the mean education year was 4.97 years. The largest education status was 12 grades complete. The mean family size of the respondents' household was about six persons while on average each household has around two economically dependent family members. In Hetosa household's head age was higher than in L/Bilbilo and they are more educated. Dependency was also higher in Lemubilbilo district and the values are all significant.

Land is the most important resource in farming business and the average landholding of the respondents was 2.59 hectares with maximum holding of 10.88 hectares and minimum holding of 0.13 hectare per household. 
Table 1. Mean of Socioeconomic Variables of Households.

\begin{tabular}{llll}
\hline Variable Description & Lemu-bilbilo & Hetosa & total \\
\hline Household head Age & $40.58^{1}$ & 51.17 & 45.28 \\
Household head education & $4.23^{2}$ & 6.54 & 4.97 \\
Dependent household member & $2.00^{3}$ & 1.37 & 1.75 \\
Family size of household & 5.92 & 5.69 & 5.83 \\
Landholding & 2.57 & 2.61 & 2.59 \\
Annual income (ETB) & 45066 & 37157 & 39689.88 \\
Livestock in TLU & 7.57 & 6.58 \\
\hline
\end{tabular}

1,2 and $3 \mathrm{t}$-value for mean difference are significant at 1,5 and $10 \%$ level.

\subsection{Description of Current Wheat Harvesting and Threshing Mechanisms}

There are two majorly used threshing mechanisms in the study areas while the third one is on introduction stage. Manual harvesting and threshing methods are the most dominating one in highlands of Lemu-Bilbilo district while in Hetosa, combine harvesting is commonly and widely used method of harvesting.Combine harvesting was re-introduced after downfall of Dergue regime by investors and unions. The third engine driven stationary thresher is under introduction by ATA and Asella agricultural engineering research center. Selamtype thresher was multiplied by ministry of agriculture and distributed to selected districts of Oromia region and Lemu-bilbilo district was the one included in the program. Asella model-III thresher was under modification and preextension demonstration since long time and currently, some farmers in Sire, Tiyo and Lemu-bilbilo districts have bought and using the technology by renting as well.

\subsubsection{Manual Sickling and Animal Threshing/Trampling (Traditional Harvesting)}

Traditional threshing method of wheat comprises activities of harvesting, heaping, transporting wheat bundles, trampling wheat on the field. This shows how much the traditional harvesting system is labor intensive and full of drudgeries. More than $75 \%$ of farmers in Lemu-Bilbilo district and only around 3\% in Hetosa threshes their wheat crop manually (in traditional ways) while the remaining is being threshed by combine harvester.

In places where traditional (manual) harvesting is common, wheat crop will be harvested by sickle and stacked in the field for some period until the farmer finishes harvesting of his others fields. Then using either back of pack animals or hoballo (sledge) drawn usually by pair of oxen or in some areas some animal drawn cart, the bundle of crop will be transported to threshing field called awudima usually prepared around the homestead where it is convenient for looking after. Bundle of wheat is transported to the nearby plate field not only for convenience but it is because the straw is highly needed for feeding livestock and also be sold for house construction purposes both in the town and rural areas. Transportation means could also be human labor depending on the availability of transporting animal or distance of the farm field from the threshing plate. Then crop bundle will be stackedor heaped again for sometimes or may directly be threshed and this will depend on need for the grain either for home consumption or market purpose, availability of animals for trampling and weather conditions suitability for threshing activity. Then the field will be cleaned of grasses and other materials and the crop will be threshed and the straw is winnowed, cleaned, measured and transported to the grain storage or warehouse sometimes.

Each activity is accomplished by human being manually using family labor or other waged labor. According to data collected using focus group discussion and checklist, harvesting (sickling) is usually done based on contract basis and the cost is between 1800 ETB and 2000ETB based on crop density while it took 16 to 20 man-days to harvest a hectare of wheat. For this research purpose average of the maximum and minimum values which was 18 mandays was considered to compute the comparative advantages of different threshing mechanisms. Even though on field heaping is done by harvesting laborers, for this consumption, the labor needed for heaping was calculated and on average 0.95 mandays per hectare was required while 0.9 mandays was needed at trampling plate. Around Meraro PAs, bundle transportation is done usually on back of pack animals (horse and donkey) while sledges (drawn by pair of oxen) and horse drawn carts were used around Lemu-dima PA. Even though it is not common around Lemu-dima PA animal renting for wheat crop transportation and trampling was common around PAs of Meraro (one of the sites this research was conducted) and it was adapted for Lemu-dima's area and used as proxy and the average rental price of 60ETB/animal day was used for computation. Most farmers in the study area keep large number of horses and oxen for trampling purposes for short period of time and some other farmers rent animals for trampling purposes.

For computation of this research work, the widely used back of pack animals; donkey and horse was used. On average to transport a hectare of crop bundle 15 donkey days and 20 man-days were used. Optionally one can also use contracting out of heaped bundle and hectare of crop was usually heaped at four places and each heap costs about 1200EBR to transport to threshing plot. Average cost of hiring a donkey day is $75 \mathrm{EBR} /$ day.

\subsubsection{Combine Harvesting Method}

In some plain of Arsi and Bale combine harvesting is commonly used and substantially reduces labor for wheat production and agricultural drudgery as a whole. Most 
farmers in these areas preferred the production of wheat over other crops because of its ease of production especiallyinweeding and harvestingprocesses. In Hetosa more than $97 \%$ of the respondents use combine harvester while it is only around $26 \%$ in Lemu-bilbilo which is mainly due to the inconvenience of topography in the area.

In previous time there were different sources of combine harvesters rent services like Agricultural Mechanization Service Stations, private owners, state farms, farmers and agricultural development experts training centers like Ardayta, and etc. But currently the market is dominated by private owners and in some areas like Hetosa, unions are providing combine rent services. Galema union also started combine harvesting service provision with two combine harvesters. Service providers are moving from place to place and their working areas are not bounded. They usually move following the crop maturity calendar from east Shewa to Bale zones. Threshing/harvesting starts in Asasa from midOctober and continues while in Hetosa it starts from November. In some highlands of Lemu-bilbilo and others it will continue up to January.

Yield estimation is done based on weight basis by operators and a quintal is equivalent to $100 \mathrm{~kg}$ while farmers measure their grain yield after re-cleaning using a polyethylene bag which contains 115 to $120 \mathrm{~kg}$ which they considered as one quintal. Sometimes this difference which is created because of misunderstand became source of dispute and loss of trust between operators and farmers. Therefore, for this computation purpose, the yield measured by farmers after re-cleaning was adjusted by the average of the difference between the two measurements. Hence, the adjusted yield was used to calculate the gross return and cost of harvesting. The adjustment value was taken to be $17.5 \mathrm{~kg}$ (i.e. a quintal of yield measured by farmers after re-cleaning was considered to be $117.5 \mathrm{~kg}$ ).

Re-cleaning of the combine harvested grain requires 0.08 man-days per quintal which is around 4.59ETB/qt based on current wage in the study areawhere comparative assessment of engine-driven stationary thresher vis-à-vis manual threshing was conducted (60ETB/day). Daily laborer's wage was around double in Hetosa during the same period and one can simply observe that how computing with the two labor intensive mechanisms in the area is too tough in this area.After re-cleaning, the grain will be packed and transported to home by animal drawn cart or pack animal and on average it costs around 5ETB per quintal and this cost is common for all the three threshing methods.

Cost of combine harvesting includes hire of combine harvester, transport with trailer, labor for re-cleaning and in most cases tip for operator. But since tip for operators is not legal and it is not uniform throughout, some farmer pay while the other were not paying, it was difficult to estimate and was not included in the cost.

Table 2. Households' use status of tractor and combine harvesting machines.

\begin{tabular}{lll}
\hline Mechanization technology & User & Non-user \\
\hline Tractor & $46(38.33)^{*}$ & $74(61.67)$ \\
Combine harvester & $47(39.2)$ & $73(60.80)$ \\
\hline
\end{tabular}

*Number in parenthesis is percentage

\subsubsection{Performance of AsellaModel-3 Multi-crop Thresher}

On farm practical participatory performance evaluation of Asella model-3 multi-crop thresher was conducted in LemmuBilbilo district at three separate sites. Two peasant associations (PAs were selected based on their wheat production potential and access to different threshing mechanisms. Three willing full farmers were selected from the two PAs for experiment. Two equal wheat crop fields $(0.125 \mathrm{ha}$ each) were prepared at each site and randomly assigned to traditional (animal trampling at hogdi/awudima) and Asella model-3 engine driven stationary threshing machine methods. The crop was first harvested by sickle and transported to threshing fields' of respective farmers. The threshing machine was operated at optimum operation speed of average drum speed 786.67RPM, and average fun speed of 1450RPM. Fuel consumption was calculated to be 1.2litters per hour.

Table 3. Machine Vs traditional method performance comparison for different parameters.

\begin{tabular}{llllll}
\hline & $\begin{array}{l}\text { Grain-straw } \\
\text { ratio(wt/wt) }\end{array}$ & cleaningefficiency & Threshingcapacity & yield/ha (thresher) & $\begin{array}{l}\text { yield/ha } \\
\text { (traditional) }\end{array}$ \\
\hline Site1 & $2: 1$ & 85.835 & $3.6 \mathrm{qt} / \mathrm{hr}$ & 30 & 24.57 \\
Site2 & $1.875: 1$ & 85.355 & $4.5 \mathrm{qt} / \mathrm{hr}$ & 35 & 30 \\
Site3 & $2: 1$ & 94 & $2.5 \mathrm{qt} / \mathrm{hr}$ & 18.7 & 16.92 \\
& - & - & - & - & 24.53 \\
Average & $1.958: 1$ & 88.40 & 3.53 & 27.90 & 2.76 \\
\hline
\end{tabular}

From table 3 above, it revealed that the machine (Asella model-III engine driven thresher) threshes 3.53 quintals $(353 \mathrm{~kg})$ of wheat per hour while the average cleaning efficiency was about $88 \%$ which is out of total threshed output, about $12 \%$ was impurity.

Costs from harvesting to transportation were all the same with that of traditional animal threshing methods and the difference is cost of threshing and cleaning. Since the straw of wheat in Arsi was used as animal feed, the wheat bundle has to be transported to nearby plate called awudima/hogdi and heaped for some times for two main reasons. The first reason was to dry out moisture of the straw for ease of threshing and the second reason was to get time until they finish harvesting other crops from their fields. 
Table 4. Man-days requirement for different threshing mechanisms.

\begin{tabular}{|c|c|c|c|c|}
\hline & & Amount & Cost & Total \\
\hline Wheat operation & Type of Labor & Required/ha & per Unit $(\mathrm{Br})$ & $\operatorname{cost} / \mathrm{ha}$ \\
\hline \multicolumn{5}{|l|}{ Manual Harvesting: } \\
\hline Harvesting & Human & 18 & 65 & 1170.0 \\
\hline Heaping in field & Human & 0.95 & 65 & 61.75 \\
\hline Heaping at threshing plot & Human & 0.90 & 65 & 58.50 \\
\hline Transportation & Human & 20 & 65 & 1300.0 \\
\hline Transportation & Donkey & 15 & 75 & 1125.0 \\
\hline Threshing & Human & 9 & 70 & 630.00 \\
\hline Threshing & Animal & 45 & 65 & 2700 \\
\hline Winnowing and bagging & Human & 6 & 65 & 390.00 \\
\hline Transportation (grain) & Lump sum & 5 & 119.15 & \\
\hline \multicolumn{5}{|c|}{ Stationary Engine Driven Thresher Threshing Method: } \\
\hline Harvesting & Human & 18 & 65 & 1170 \\
\hline Heaping in field & Human & 0.95 & 65 & 61.75 \\
\hline Heaping at threshing plot & Human & 0.9 & 65 & 58.50 \\
\hline Transportation & Human & 20 & 65 & 1300 \\
\hline Transportation & Donkey & 15 & 80 & 1125 \\
\hline Machine cost & Machine & 1 & 355.75 & \\
\hline Fuel cost & Fuel & 1.2lit & 16.16 & 153.3 \\
\hline Operator & Human & 3 & 65 & 192.70 \\
\hline Winnowing & Human & $0.08 / \mathrm{qt}$ & 65 & 145.1 \\
\hline Transportation (grain) & Lump sum & 5 & 139.5 & \\
\hline \multicolumn{4}{|c|}{ Total variable cost for engine driven threshing mechanism } & 4701.6 \\
\hline
\end{tabular}

\subsection{Financial Profitability Analysis of the Mechanisms}

To compare financial profitability of the three threshing mechanisms, traditional manual harvesting and animal trampling, manual harvesting and stationary engine driven machine threshing and combine harvesting techniques, partial budgeting was employed (Table 5). For the two threshing mechanisms (manual and motorized thresher) even though threshing/harvesting cost per quintal is different as grain yield per quintal is different for the two threshing mechanisms, since the crop has to be harvested first using sickle, they both share same all costs from harvesting to transporting to threshing fields.

Table 5. Financial profitability (Birr/ha) of wheat harvesting and threshing technologies in Arsi (Lemu-bilbilo district).

\begin{tabular}{|c|c|c|c|}
\hline & ManualHarvesting & ThresherHarvesting & CombineHarvesting \\
\hline Yield (qt/ha) & 23.83 & 27.90 & 26.17 \\
\hline Gross returna & 20255.55 & 23715 & 24590.50 \\
\hline \multicolumn{4}{|l|}{ Cost of manual harvesting: } \\
\hline Labor for Harvesting & 1170 & 1170 & - \\
\hline Labor for Heaping & 120.25 & 120.25 & - \\
\hline Labor for Transportationb & 1300 & 1300.0 & - \\
\hline Labor for Threshing ${ }^{\mathrm{c}}$ & 1200 & - & - \\
\hline Labor for winnowing $^{\mathrm{d}}$ & 630 & - & - \\
\hline Animal labor ${ }^{\mathrm{e}}$ & 3825 & 1125 & - \\
\hline Material cost & 58.75 & 58.75 & - \\
\hline Labor for operation & - & 192.51 & - \\
\hline Labor (re-cleaning and weighing) & - & 145.08 & - \\
\hline Machine cost ${ }^{\mathrm{f}}$ & 355.50 & & \\
\hline \multicolumn{4}{|l|}{ Cost of combine harvesting (ETB/ha) } \\
\hline Hire of combine harvester & 1731.60 & & \\
\hline Transport with trailer & 288.60 & & \\
\hline Labor (re-cleaning and weighing) & 136.08 & & \\
\hline Transport with cart/donkey & 130.85 & & \\
\hline Total costs that vary & 8304 & 4667.09 & 2287.13 \\
\hline Net income after varying cost & 11591.55 & 19247.91 & 19957.37 \\
\hline
\end{tabular}

${ }^{a}$ average price of 850 ETB per quintal was taken (data from farmers and DAs)

${ }^{b}$ for transportation of wheat bundle, 1.33 man-day is needed per a donkey (20man-days vs 15 donkey days)

${ }^{\mathrm{e}}$ animal labor for manual threshing includes animal for threshing and transporting bundles from field to awdima while in motorized thresher case it includes only animal labor for transportation

${ }^{\mathrm{f}}$ Refer Appendices I - IV for machine cost computation 
Own combine harvesting at small scale farming level like that of Ethiopia is unthinkable therefore, cost of harvesting by combine harvester was calculated based on cost of hiring the machine on quintal basis. In some cases, when the operators perceived that land productivity of specific farm is not good, they prefer to cost based on land size. But since this happen in rare cases, only cost per quintal basis was used for this particular research.

For motorized stationary engine driven threshers, since owing the machine at least in group basis is possible, the threshing cost if the machine was owned was calculated. Cost of threshing in this case includes machine owing costs, machine operating cost, and harvesting and transportation costs.

\subsection{Economic Advantages of Wheat Threshing Mechanisms}

\subsubsection{Machine Payback Period and Sensitivity Analysis}

A machine pay-back period is a consecutive time in a machine's expected economic life that a machine's purchase price could be re-gained from its services. It was assumed that one human day is equivalent to eight hours working and three human days was needed to work on a machine. A machine was estimated to work for about $200 \mathrm{hrs}$ and can thresh a total of about 706 quintals of wheat per a year. Labor to thresh this amount of wheat was three person-days per a day times twenty five (i.e. if a machine works for full-time which is for eight hours, it took 25 days in a year to work for total of 200 hours) days (Table 6).

Table 6. Cost and returns of machine per a year.

\begin{tabular}{llll}
\hline Cost item & quantity & unit price & total cost \\
\hline Total labor cost & $3 \mathrm{PD}^{*} 65 \mathrm{Br} /$ day*25days & 65 & $4875 /$ year \\
Fuel cost & 1.2 lit/hrs*200hrs & 16.16 & $3878.4 /$ year \\
Total variable cost & & & \\
Total machine owing cost/year $(200 \mathrm{hrs})$ & $45 * 200 \mathrm{hrs}$ & 9000.00 & $8753.4 \mathrm{ETB} /$ year \\
$\begin{array}{l}\text { Total overall cost per year } \\
\text { Gross annual return }\end{array}$ & & & \\
Net income per a year & $706 \mathrm{qt}$ & $55 \mathrm{ETB} / \mathrm{qt}$ & $17,753.4 \mathrm{ETB}$ \\
\hline
\end{tabular}

Currently farmers who bought engine driven multi-crop threshing machine from Asella AERC are renting a machine for 55ETB per a quintal and machine owners only supply machine operator (one person-day per a machine). The gross return per a year from machine rent will be $3.53 \mathrm{qt} / \mathrm{hr} * 200 \mathrm{hrs} / \mathrm{year} * 55 \mathrm{ETB} / \mathrm{qt}$ which is equals to $38,830 \mathrm{ETB}$. The net income from the rent of threshing machine will be the difference between gross return and total overall cost per year and it is $21,076.60 \mathrm{ETB}$ per year. Therefore, if one buy and rent a machine the machine payback period will be around two and half years.

Sensitivity analysis of the investment should be assessed at three stages, under normal, intermediate and worst scenarios. In this case the worst scenario could be when the service charge is reduced to charges equivalent to combine harvesting charges given around Etheya and GedebAsasa districts where topography is more suitable for combine harvesting and there is large supply of service. In these areas, the hiring service market is at competitive basis and the charge during period was $40 \mathrm{ETB}$ per quintal.Therefore, if the service charges of engine driven wheat thresher reduced to $40 \mathrm{ETB} /$ quintal, the net income will be reduced to $19,486.60$ ETB and the payback period will be around two years.

\subsubsection{Internal Rate of Return (IRR) for Asella Model-III Multi-crop Thresher}

Table 7. Machine Investment Cash Flow.

\begin{tabular}{lll}
\hline Year & Cash Flow & Amount (ETB) \\
\hline Year 0 & (investment) & $-47,000.00$ \\
Years 1-10 & $21076.60 /$ year & \\
IRR & $44 \%$ & \\
\hline
\end{tabular}

The Internal rate of return (IRR) for an investment is the percentage rate earned on each birr invested for each period it is invested. Mathematically, internal rate of return (IRR) is the interest rate at which the net present value of all the cash flows (both positive and negative) from a project or investment equal zero. In this case it is the IRR for investment on the OARI-Asella model-III multi-crop thresher. The cash flow includes initial investment and the net income from the rent of machine for the next consecutive ten years. The result revealed in Table 7 that the internal rate of return for the machine was $44 \%$ which is much higher than the interest paid on saving by commercial banks. This amount is also by far greater than the loan interest rate (17\%) levied by financial institutions like Oromia Credit and Saving Association (WALQO) at a time this study was conducting.

\subsection{Need Assessment for Willing to Use Asella Model-III Multi-crop Thresher}

Simple assessment was conducted on farmers who attended during evaluation of the machine at Lemu-Bilbilo district andothers who were not there during evaluation but knows about Asella multi-crop thresher both in Hetosa and Lemu-bilbilo through questionnaires were filled to find if they were willing to use the machine and if they are willing, the mode of owning the machine. Accordingly, all the participants were willing to use the machine either through buying in group or through renting. Respondents from Hetosa district preferred the machine as an option and for some pocket and inaccessible plots while those in Lemubilbilo district; the machine under evaluation was the only choice to mechanize their farm at current situation. 
Around 28\% (34 out of 120) of farmers were willing to buy the machine in group while around $69 \%$ (47 out of 65 ) of them were willing to use in rental basis and around $3 \%$ were willing to buy the machine individually.

\section{Conclusion}

For this research activity data was generated in two way namely survey type and on field economic evaluation of the three threshing mechanisms (combine harvesting, engine driven stationary multi-crop thresher threshing and manual threshing). Generally, the result of survey revealed that in Arsi zone, wheat farm is the most relatively mechanized enterprise specially in districts located on main road from Adama to Bale and have conducive topography for large agricultural machineries namely tractor and combine harvester. In Hetosa, one of the most accessible districts in Arsi zone, more than 90 percent and $75 \%$ of the households were using combine harvester and tractor for wheat production respectively. For those inaccessible areas, the most dominantly used wheat threshing mechanism was manual sickling and animal trampling mechanism. The stationary engine driven threshing mechanism was at popularization stage by ministry of agriculture and Asella agricultural engineering research center. The center released its' third model thresher which has overall performance of $3.53 \mathrm{qt} /$ hour threshing capacity and 88.4 percent clearing efficiency. Cost of threshing were 2287.13, 4667.09 and 8304ETB for combine harvesting, engine driven thresher and manual harvesting mechanisms while the net income after varying costs were 19957.37, 19247.13 and 11591.55ETB respectively. The payback period for engine driven stationary threshing machine was calculated to be around two and half years. The thresher has additional advantage of straw chopping which facilitates its' palatability for animals as feed. Moreover, the machine is profitable if one buy and rent for others with internal rate of return of around $44 \%$.

\section{Recommendation}

From the result of both survey and economic analysis on farmers' field it can be concluded that specific recommendation is important. Based on the result from on field economic evaluation of the threshing mechanisms, engine driven stationary threshing mechanism was economical over the traditional mechanism. Therefore, further and wider promotion should be planned jointly with stakeholders and the technology transferring mechanism to private manufacturers should be built. In mean time the government should interfere to create demand for private manufacturers through pre-scaling up of the technology using different approach like availing credit facilities, cooperatives and unions and grouping farmers for further use and the like.

Furthermore, the center's farm machinery research team should work on the improvement of the threshing capacity of the machine as the price of machine including its engine and its capacity are not comparable to maximize the benefit of farmers'/users' from his investment on the machine.

\section{Appendixes}

\section{Appendix I. Cost of operating Stationary Engine Driven AsellaModel-III Multi-crop Thresher}

Labor cost to operate the machine: three person days

Fuel cost: 1.2 lit/hr (1.2litter*16.16ETB/litter $)=19.392 \mathrm{ETB}$

It was estimated that the machine can serve for 200 hours per annum and serve for total of 2000hours (expected life of the machine is 10years)

Appendix IV. Computation for cost of owing stationary Engine driven Asella model-III multi-crop thresher

1. Salvage value $=10 \%$ of purchase price

2. Average investment cost $=$ (purchase price + salvage value) $/ 2$

3. Depreciation cost $=$ (purchase price - salvage value)/total life period of machine

4. Insurance $=1.5 \%$ of Average investment cost

5. Interest cost $/ \mathrm{hr}=6 \%$ of average investment cost $/$ total hrs used per annum $(6 \% *$ Average investment cost $) / 200 \mathrm{hrs}$

6. Repair and maintenance cost per hour $=50 \%$ of purchase price/total useful life of the machine $(50 \% * 29,000) / 2000$

N.B: Cost of owing Engine for thresher can also be computed similarly:

\section{Appendix II. Data on Combine Harvester}

\begin{tabular}{|c|c|c|c|c|c|}
\hline Land Size & Operator estimationyield & $\begin{array}{l}\text { Re-cleaned yield T } \\
17.5 \mathrm{~kg}\end{array}$ & costAfter adjusted by & $\begin{array}{l}\text { Labor (re-clean) } \\
\text { (combine harvesting) }\end{array}$ & $\begin{array}{l}\text { Transport to of } \\
\text { Awdima }\end{array}$ \\
\hline $13416 \mathrm{~m}^{2}$ & 36 & $32.9(24.53 \mathrm{qt} / \mathrm{ha})^{*}$ & $60 \mathrm{Br} / \mathrm{qt}$ & $2 * 60=120$ & $10 \mathrm{Br} / \mathrm{qt}(36 * 10)$ \\
\hline $5000 \mathrm{~m}^{2}$ & 25 & $21.38(42.76 \mathrm{qt} / \mathrm{ha})$ & $60 \mathrm{Br} / \mathrm{qt}$ & $1 * 60=120$ & $10 \mathrm{Br} / \mathrm{qt}\left(25^{*} 10\right)$ \\
\hline $4290 \mathrm{~m}^{2}$ & 13 & $11.93(27.81 \mathrm{qt} / \mathrm{ha})$ & $60 \mathrm{Br} / \mathrm{qt}$ & $2 * 60=120$ & $10 \mathrm{Br} / \mathrm{qt}(13 * 10)$ \\
\hline $12321 \mathrm{~m}^{2}$ & 27 & $25.38(20.6 \mathrm{qt} / \mathrm{ha})$ & $60 \mathrm{Br} / \mathrm{qt}$ & $2 * 60=120$ & $10 \mathrm{Br} / \mathrm{qt}(27 * 10)$ \\
\hline Average & 28.86 & $26.17 \mathrm{qt} / \mathrm{ha}$ & $60 \mathrm{qt} / \mathrm{ha}$ & $0.08 \mathrm{~m}-\mathrm{d} / \mathrm{qt}$ & $10 / \mathrm{qt}^{* *}$ \\
\hline
\end{tabular}

*The number in the parenthesis are yield computed per hectare while the one out of the parenthesis is real measured yield on the given plot size

**Transportation cost (either by truck or combine harvester itself) is calculated based on yield estimated by operators 
Appendix III. Machine and Engine Owing Cost Calculation

\begin{tabular}{|c|c|c|c|c|c|c|c|c|c|}
\hline Machine & $\begin{array}{l}\text { purcha } \\
\text { (P) }\end{array}$ & & $\begin{array}{l}\text { Average } \\
\text { life(h) }\end{array}$ & $\begin{array}{l}\text { Average used } \\
\text { time/Annum }\end{array}$ & $\begin{array}{l}\text { Salvage } \\
\text { value } \\
(10 \% P)\end{array}$ & $\begin{array}{l}\text { Average } \\
\text { Investment cost }\end{array}$ & $\begin{array}{l}\text { Depreciation } \\
\text { cost }\end{array}$ & Insurance & Interest cost \\
\hline Thresher & 29,000 & & 2000 & 200 & 2900 & 30450 & 13.05 & 0 & 9.135 \\
\hline Engine & 18000 & & 2000 & 200 & 1800 & 9900 & 8.1 & 0 & 2.97 \\
\hline Total & 47,000 & & 4,000 & 400 & 4,700 & 40,350 & 21 & 0 & 12 \\
\hline Machine & TFC & \multicolumn{2}{|c|}{$\begin{array}{l}\text { TFC excluding } \\
\text { interest }\end{array}$} & \multicolumn{2}{|c|}{$\begin{array}{l}\text { Repair \& maintenance cost } \\
\text { as \% of purchase price }\end{array}$} & $\begin{array}{l}\text { Repair and } \\
\text { maintenance cost }\end{array}$ & TVC & TC Br/hr & $\begin{array}{l}\text { TC excluding } \\
\text { interest }\end{array}$ \\
\hline Thresher & 22.19 & \multicolumn{2}{|c|}{13.05} & \multicolumn{2}{|l|}{$50 \%$} & 7.25 & 7.25 & 29.44 & 20.3 \\
\hline Engine & 11.07 & \multicolumn{2}{|l|}{8.1} & \multicolumn{2}{|l|}{$50 \%$} & 4.5 & 4.5 & 15.57 & 7.47 \\
\hline Total & 33 & \multicolumn{2}{|l|}{21} & \multicolumn{2}{|l|}{1} & 12 & 12 & 45 & 28 \\
\hline
\end{tabular}

N.B: Machine cost per a hectare for average yield per hectare of 27.9qt/ha was 355.5ETB (7.9hrs to thresh $27.9 \mathrm{qt}$ of wheat) and cost per hr of machine was 45ETB.

N.B. Computation is based on [11].

\section{References}

[1] CADU (Chilalo Agricultural Development Unit). 1969. Progress Report No. 1. Implement Research Section. CADU Publication No. 32.

[2] CADU (Chilalo Agricultural Development Unit). 1970. Progress Report No. 2. Implement Research Section. CADU Publication No. 52.

[3] CADU (Chilalo Agricultural Development Unit). 1971. Progress Report No. 3. Implement Research Section. CADU Publication No. 79.

[4] sJonsson, L-O. 1972. Possibilities for Improvement of Threshing Methods on the Ethiopian Highlands. Rural Development Publication No. 1.

[5] HenockKifle. 1972. Investigations on Mechanized Farming and its Effect on Peasant Agriculture. CADU Publication No. 74.

[6] Holmberg, J. 1972. Master Plan for the Evaluation of CADU.

Planning and Evaluation Section CADU Publication No. 81.

[7] Michael Stàhl, 1973: Contradiction in Agricultural Development; A study of three minimum package projects in southern Ethiopia; The Scandinavian Institute of African Studies; Uppsala.

[8] Hassena, M., Regassa Ensermu, W. Mwangi, and H. Verkuijl., 2000. A Comparative Assessment of Combine Harvesting Visà-vis Conventional Harvesting and Threshing in Arsi Region,Ethiopia. Mexico, D. F.: International Maize and Wheat Improvement Center (CIMMYT) and Ethiopia Agricultural Research Organization (EARO).

[9] Binswanger, H. 1978. The Economics of Tractors in South Asia: An Analytical Review. Hyderabad, India: International Crops Research Institute for the Semi-Arid Tropics (ICRISAT).

[10] Gittinger, J.P. (1996), Economic Analysis of Agricultural Project, Washington, D.C. World Bank.

[11] Kwazulu-Natal Agriculture, Environmental Affairs and Rural Development, 2013.Guide to machinery costs available on www.daff.gov.za/publications. 